Jan Paweł II. Posługa myślenia, t. 2, red. ks. B. Kastelik, A. Krupka, ks. R. Woźniak, Kraków 2015, s. 321-340 (Studia nad Myślą Jana Pawła II, 17).

DOI: http://dx.doi.org/10.15633/9788374384933.15

ks. Krzysztof Kaucha

\title{
ARGUMENTY ZA WIARYGODNOŚCIĄ KOŚCIOLA W ŚWIETLE NAUCZANIA ŚW. JANA PAWŁA II
}

Główną treścią niniejszego artykułu będzie syntetyczna prezentacja kilkunastu argumentów za wiarygodnością Kościoła, które zostały wydobyte niemal z całego nauczania Jana Pawła II, w trakcie naukowego badania tego nauczania w ramach teologii fundamentalnej.

Cel tej prezentacji jest dwojaki. Po pierwsze praktyczno-apologijny. Dziś bowiem Kościół jest przedmiotem ostrej krytyki czy jest wprost odrzucany, czego wyrazem jest np. powiedzenie „Chrystus - tak, Kościół - nie”, a chrześcijanie chcący bronić swej religii i jej eklezjalności - nie tylko znajdujący się „na pierwszej linii frontu", jak katecheci czy dziennikarze katoliccy, lecz także znajdujący się na dalszych liniach - powinni otrzymać skuteczną do tego pomoc. Może nią być szeroki wachlarz uporządkowanych racji przemawiających za wiarygodnością (nadprzyrodzonością, autentycznością, skutecznością, potrzebą) Kościoła wydobytych z nauczania Jana Pawła II. Chodzi też o pomoc dla tych chrześcijan, którzy pod wpływem współczesnej antyeklezjalności tracą lub już utracili więź z Kościołem, dając sobie wmówić, że jest on tworem wyłącznie ludzkim. Po drugie, celem prezentacji jest popularyzacja efektów badań naukowych nad nauczaniem świętego papieża Polaka, do którego nadal w Polsce podchodzi się przede wszystkim emocjonalnie i którego wspomina się tylko przy okazji rocznic z nim związanych, przypominając wyrwane z jego nauczania cytaty.

Na strukturę tego artykułu składać się będzie omówienie badań naukowych przeprowadzonych przez autora (punkt 1) oraz krótkie prezentacje piętnastu konkretnych argumentów podzielonych na cztery następujące grupy: argumenty historyczne, duchowo-moralne, kulturowo-społeczne i polityczno-ekonomiczne (punkty 2-5). 


\section{Badania naukowe nad wiarygodnością Kościoła w kontekście wyzwań współczesności europejskiej}

W tym punkcie zostaną omówione kilkuletnie autorskie badania naukowe, podjęte $\mathrm{z}$ racji przygotowywania rozprawy habilitacyjnej z zakresu teologii fundamentalnej.

Ta dyscyplina teologiczna zajmuje się badaniem i uzasadnianiem wiarygodności religii chrześcijańskiej i jest kontynuacją, po koniecznych zmianach metodologicznych, tzw. apologetyki. Jej celem jest badanie i uzasadnianie poprzez rzetelną argumentację - wiarygodności chrześcijaństwa. W klasycznym ujęciu teologia fundamentalna składa się z trzech następujących subdyscyplin: religiologii (badającej fenomen religii zwłaszcza pod kątem genezy, istoty, funkcji i prawdziwości), chrystologii fundamentalnej (badającej i uzasadniającej wiarygodność objawienia chrześcijańskiego, którego pełnia pochodzi od Jezusa Chrystusa) i eklezjologii fundamentalnej (badającej i uzasadniającej wiarygodność Kościoła). Przedmiotem formalnym tej dyscypliny - jak widać - jest wiarygodność. Ogólnie rzecz ujmując, jest ona w teologii fundamentalnej rozumiana jako cecha lub zespół cech przedmiotu, który jest niemożliwy do bezpośredniego poznania, ze względu na które to właściwości przedmiot ten zasługuje na afirmację i zaangażowanie człowieka. Badając i starając się uzasadnić wiarygodność Kościoła - w ramach eklezjologii fundamentalnej - teologia fundamentalna zmierza do wykazania jego nadprzyrodzoności, boskiej genezy, pełni Bożego objawienia, obecności Boga i zbawczej skuteczności.

W Polsce teologia fundamentalna jest uprawiana w wielu ośrodkach, m.in. w tzw. lubelskiej szkole teologii fundamentalnej, w której piszący te słowa odbył edukację w zakresie studiów magisterskich i doktoranckich, uzyskując stopień doktora teologii. Został do tej szkoły włączony poprzez angaż w Instytucie Teologii Fundamentalnej Katolickiego Uniwersytetu Lubelskiego w 1997 roku. Podstawy tej szkoły tworzył ks. prof. Edward Kopeć (1918-1999), zaś ukształtował ją ks. prof. Marian Rusecki (1942-2012), który ukierunkowywał autora niniejszego artykułu w stronę problematyki eklezjologicznofundamentalnej.

Około roku 2004, po zakończeniu prac związanych z organizacją II Międzynarodowego Kongresu Teologii Fundamentalnej Chrześcijaństwo jutra (18-21 IX 2001) i wydaniem Leksykonu teologii fundamentalnej (2002) - dzieł dokonanych przez Instytut Teologii Fundamentalnej KUL - piszący te słowa przystąpił do przygotowywania rozprawy habilitacyjnej. Od początku chciał 
podjąć temat wiarygodności Kościoła w kontekście wyzwań współczesności europejskiej, jako że właśnie te wyzwania wydawały się Kościół najbardziej kontestować. Współczesna Europa - z propagowaną w niej indywidualną wolnością religijną, selektywnością wiary, prywatyzacją wiary, dominacją poznania naukowego, przejmowania przez instytucje państwowe działalności charytatywnej i opiekuńczej - wydawała się stanowić dla Kościoła, nie tylko rzymskokatolickiego, największą próbę wiarygodności. Dlatego roboczy temat rozprawy habilitacyjnej został sformułowany jako „wiarygodność Kościoła w kontekście wyzwań współczesności europejskiej”.

Racjonalne i logiczne wydawało się, by - zgodnie z metodologią teologii fundamentalnej jako tzw. dyscypliny pogranicza - najpierw wydobyć wyzwania stojące przed Kościołem na podstawie literatury tzw. zewnętrznej, czyli pozateologicznej, głównie opracowań socjologicznych i filozoficznych. Jednak po zapoznaniu się z nimi okazało się, że zamierzonego projektu nie da się w ten sposób zrealizować. W opracowaniach tych występują nie tylko różne rozumienia współczesnych wyzwań (nawet rozumienia sprzeczne, gdyż co dla jednych jest wyzwaniem-problemem, dla innych jest postępem i na odwrót), lecz także odmienne koncepcje danej nauki, np. socjologii.

Tak zrodził się pomysł, by jako źródło badań obrać literaturę teologicznofundamentalną, polską i zagraniczną. Jednak po jej wstępnej analizie okazało się, że brak w niej gruntownych analiz dążących do ujęcia wyzwań współczesności europejskiej.

W takiej sytuacji z pomocą przyszedł ks. prof. Marian Rusecki, który na jednym z seminariów z teologii fundamentalnej w roku 2005 - krótko po śmierci Jana Pawła II - zaproponował, by jako źródło do badań wybrać papieskie nauczanie. Piszący te słowa podjął ten trop i od razu rozpoczął gromadzenie materiału źródłowego oraz badania naukowe. Trwały one od drugiej połowy 2005 roku do pierwszej połowy 2008 roku, gdy została ukończona i oddana do druku rozprawa habilitacyjna pod tytułem Wiarygodność Kościoła w kontekście wyzwań wspótczesności europejskiej w świetle nauczania Jana Pawła II ${ }^{1}$.

Badania polegały na naukowej analizie całego nauczania Jana Pawła II, zwłaszcza odnoszącego się do Europy, pod kątem wyzwań stojących przed Kościołem, ich diagnozy oraz wiarygodności Eklezji w ich kontekście. Mówiąc konkretnie, najpierw zapoznano się z nauczaniem papieża Polaka - ogólnokościelnym oraz dotyczącym problematyki europejskiej - z którego wydobyto

\footnotetext{
$1 \quad$ Lublin 2008.
} 
wyzwania. Potem poszukiwano ich papieskiej diagnozy (rozumienia, etiologii, skutków, powiązań), zwłaszcza pod kątem zagadnienia wiarygodności Kościoła. Jednocześnie starano się znaleźć odpowiedź na pytanie, jak w obliczu tych wyzwań Jan Paweł II rozumiał i uzasadniał wiarygodność Eklezji. Oprócz ogólnych uzasadnień, np. że nie ma chrześcijaństwa bez Kościoła (bezkościelnego), wykryto w papieskim nauczaniu piętnaście argumentów, czyli zespół powiązanych ze sobą licznych przesłanek, które nie tyle zrekonstruowano, ile scalono i usystematyzowano. Posłużono się tu kluczem „czterech źródeł” obecnym w papieskiej myśli, wskazując, że niemal wszystkie argumenty mają uzasadnienie historyczne, kontekstualne, pozakontekstualne i pochodzące z objawienia chrześcijańskiego. Jako że w trakcie badań zauważono, iż w całej ludzkiej rzeczywistości Jan Paweł II wyróżniał cztery wymiary, a mianowicie historyczny, duchowo-moralny, kulturowo-społeczny oraz polityczno-ekonomiczny, owe argumenty zgrupowano. Do płaszczyzny historycznej zaliczono argumenty z bilansu obecności Kościoła w dziejach Europy, europotwórczy, rekoncyliacyjny, sperancyjny, martyrologiczny i misyjny; do duchowo-moralnej - argumenty antropologiczno-wokatywny, metafizyczny i etyczny; do społeczno-kulturowej argumenty kulturotwórczy, aksjologiczny i komuniotwórczy, a do polityczno-ekonomicznej argumenty prakseologiczny, z wolności religijnej oraz z projektu Kościoła co do integracji europejskiej.

Z powodu ograniczonej objętości prezentacja papieskich argumentów za wiarygodnością Kościoła nie będzie tu całościowa, lecz skrótowa i z zastosowaniem języka bardziej popularyzującego (jako bardziej komunikatywnego) niż ściśle naukowego. Dążyć się w niej będzie przede wszystkim do oddania istoty poszczególnych argumentów. Z racji charakteru niniejszego artykułu niewiele w nim będzie odnośników do konkretnych papieskich tekstów. Czytelników tym zainteresowanych należy odesłać do książki Wiarygodność Kościoła w kontekście wyzwań wspótczesności europejskiej w świetle nauczania Jana Pawła II i zawartej w niej bibliografii.

\section{Argumenty historyczne}

Stwierdzenie, że historyczność składa się z przeszłości, teraźniejszości i przyszłości, które na siebie oddziałują, nie stanowi żadnego novum. Diagnozując współczesność Europy i Kościoła, Jan Paweł II uwzględniał przeszłość, a także perspektywę przyszłości. Mając to na uwadze, opracowane na podstawie jego nauczania argumenty historyczne za wiarygodnością Eklezji 
można podzielić na odwołujące się do przeszłości (argument $\mathrm{z}$ bilansu obecności Kościoła w dziejach Europy, europotwórczy i rekoncyliacyjny) oraz uwzględniające przyszłość (sperancyjny, martyrologiczny i misyjny).

\subsection{Argument $z$ bilansu obecności Kościoła $w$ dziejach Europy $y^{2}$}

Jeśli chce się rozstrzygnąć kwestię wiarygodności czy niewiarygodności Kościoła w kontekście europejskim, to najrzetelniej byłoby dokonać najpierw bilansu jego obecności w dziejach Starego Kontynentu. Taką drogę sugeruje nauczanie Jana Pawła II, w którym często zwracał on uwagę na bardzo pozytywny wpływ Eklezji. Reagował także na zaniedbania czy wprost grzechy ludzi Kościoła popełnione w przeszłości. Podejmował również kwestie kontrowersyjne - bądź wyjaśniając je w duchu apologijnym, bądź inicjując badania historyczne w celu ich gruntownego zbadania (przykładem jest tu tzw. sprawa Galileusza). Dotyczyło to m.in. następujących zagadnień: przypadków nieposzanowania duchowego dorobku misjonowanych kultur, wewnętrznych problemów Kościoła w średniowieczu (problemy polityczne, nepotyzm, moralne i dyscyplinarne zaniedbania kleru), relacji do narodu żydowskiego, przyczyn rozbicia jedności Kościoła, grabieży Konstantynopola na początku XIII wieku, sprawy Jana Husa, tzw. wojen religijnych, działania inkwizycji, sprawy Galileusza, zbyt późnej reakcji na tzw. kwestię społeczną, marginalizacji kobiet, zarzutu o pośrednie uczestnictwo chrześcijan w Zagładzie Żydów w czasie II wojny światowej, przypadków wspierania przez chrześcijan nacjonalizmów dopuszczających się aktów przemocy ${ }^{3}$.

Jednocześnie Jan Paweł II przypominał o niezwykle pozytywnych skutkach obecności Kościoła w dziejach Europy. Niektóre, bardziej „punktowe”, dałoby się szczegółowo przedstawić w porządku chronologicznym, np. oczyszczenie kultury antycznej z ograniczonego humanizmu i zawężonej demokracji, tworzenie szkół i uniwersytetów, instytucji charytatywnych, synteza chrześcijaństwa i nowego humanizmu na początku odrodzenia, arcydzieła myśli, literatury, architektury, malarstwa i muzyki, rewolucja sumień w 1980 roku. Według papieża są też inne, które można dostrzec jedynie dzięki historiozoficznej lekturze całych dotychczasowych dziejów Europy, o których szerzej będzie mowa w kolejnym punkcie niniejszego artykułu.

${ }^{2} \quad$ K. Kaucha, Wiarygodność Kościoła w kontekście wyzwań współczesności europejskiej $w$ świetle nauczania Jana Pawła II, s. 44-53.

3 Zob. tenże, Apologia Kościoła w nauczaniu Jana Pawła II, [w:] Rok wiary - rok odnowy, red. K. Kaucha, A. Pietrzak, W. Rebeta, Lublin 2013, s. 102-110. 


\subsection{Argument europotwórczy}

De facto nigdzie w swym nauczaniu Jan Paweł II nie posłużył się określeniem „argument europotwórczy”, jednakowoż na podstawie tego nauczania można go sformułować. Jego punktem wyjścia byłoby podstawowe pytanie oczywiste, choć rzadko zadawane - kiedy i jak doszło do powstania Europy jako zwartego kulturowego wzorca cywilizacyjnego? I jeszcze mocniej: jaki był warunek sine qua non powstania Europy (nie ma potrzeby wspominać tu o przyczynach oczywistych, jak np. terytorium, ludzie, podstawowe narzędzia do tworzenia i przekazywania kultury)?

Choć rzecz jasna tworzenie się Europy było procesem rozłożonym w długim czasie, to jednak - według Jana Pawła II - można bez trudności wskazać jego najważniejsze przyczyny, a nawet paradoks, który uprawnia do wydobycia racji przekraczających porządek naturalnych procesów historycznych. Przyczynami naturalnymi były liczne kultury, które powstały na terenach dzisiejszej Europy (grecka, rzymska, celtycka, germańska, słowiańska, ugrofińska, żydowska i muzułmańska). Jednak nie jest zrozumiałe, dlaczego te zróżnicowane kultury w określonym momencie dziejowych zaczęły tworzyć kulturowo-ideową jedność w postaci cywilizacji, która do dziś może być traktowana jako wzorcowa. Tym decydującym czynnikiem i warunkiem sine qua non powstania Europy było dla papieża chrześcijaństwo i jego ukonkretnienie, a mianowicie Kościół. Jego pojawienie się na dzisiejszych terenach europejskich okazało się przełomem w dziejach świata. Europa jako pierwszy kontynent otworzyła się na nową religię, a ona w zamian doprowadziła do zrodzenia się nowej jakości cywilizacyjnej. Chrześcijaństwo wniosło nieznane w świecie starożytnym - choć, jak się wyraził papież, oczekiwane i przeczuwane - wartości i koncepcje, takie jak: koncepcję osoby, godność i świętość człowieka, prymat wartości duchowo-moralnych, prawa człowieka, ideę dobra wspólnego, pomocniczości i solidarności, centralną rolę rodziny, demokrację, wartość pracy, powołania, bezinteresowności. Dzięki nim ukształtowała się tożsamość Europy wyrażająca się w jej kulturze obejmującej ponadczasowe arcydzieła myśli i sztuki.

Argument europotwórczy jest dziś osłabiany przez krytykę europocentryzmu za liczne jego przejawy, zwłaszcza polityczne i ekonomiczne. Jednak trzeba zwrócić uwagę, że Jan Paweł II nie był bezkrytycznym piewcą Europy czy europocentrykiem. Krytycznie oceniał zarówno wewnętrzne, jak i zewnętrzne

Tenże, Wiarygodność Kościoła w kontekście wyzwań współczesności europejskiej $w$ świetle nauczania Jana Pawła II, dz. cyt., s. 53-57. 
błędy Europejczyków. Uważał, iż ich podłożem zawsze było uprzednie odejście od fundamentu i tożsamości Europy, zwłaszcza chrześcijaństwa. Na ogół ich skutkiem było cierpienie wielu ludzi, a także umacnianie się nienawiści między narodami Europy. Fakt ten daje podwaliny pod kolejny argument za wiarygodnością Kościoła, szkicowany w papieskim nauczaniu.

\subsection{Argument rekoncyliacyjny ${ }^{5}$}

Za wiarygodnością Kościoła w dziejach Europy przemawia zdaniem Jana Pawła II jego niezaprzeczalne działanie rekoncyliacyjne (łac. reconciliatio pojednanie), które dokonywało się i dokonuje w wielu formach. Jak wyżej wspomniano, papież zwracał uwagę na to, że dzieje Starego Kontynentu obfitowały w wydarzenia negatywne, wręcz haniebne, jak wojny, prześladowania, dyskryminacje, totalitarne ideologie, obozy koncentracyjne, gułagi, czystki etniczne. Apogeum ludzkiego cierpienia, nienawiści i zła nastąpiło w XX wieku, nazywanym przez papieża „stuleciem wielkich niedoli człowieka” i triumfem „cywilizacji śmierci”. Wielokrotnie mówił on o paradoksie, że w tamtym właśnie wieku - nie tak odległym w czasie - ogrom zła pojawił się na terenie kontynentu, który jako pierwszy w dziejach świata przyjął chrześcijaństwo.

Jan Paweł II wykazywał, że nigdy w dziejach Starego Kontynentu Kościół nie zaprzestawał działalności rekoncyliacyjnej, wzywając do pojednania zwaśnionych ludów i narodów, przebaczenia win, przyznania się do nich i oczyszczenia pamięci. Co innego, że apele Kościoła zarówno w przeszłości, jak i obecnie bywają lekceważone ze względu na korzyści czerpane przez niektóre grupy interesu z podtrzymywania, a nawet rozniecania nienawiści i uprzedzeń. W swej aktywności rekoncyliacyjnej Kościół był i jest konsekwentny, działając na rzecz pokoju i pełnego pojednania (pełne pojednanie obejmuje uznanie swej winy, przeproszenie, przebaczenie drugiemu, niepamiętanie złego - tzw. oczyszczenie pamięci).

Nie chodzi tu zresztą o same zewnętrzne efekty tej działalności, lecz przede wszystkim motywację płynącą z wnętrza, tożsamości Eklezji. Chrześcijańska wiara wyrasta bowiem z przebaczenia grzechów dokonanego zwłaszcza w męce, śmierci i zmartwychwstaniu Jezusa Chrystusa, a wierzący w Niego są wezwani do nieustannego przebaczenia innym, modlitwy za nieprzyjaciół, miłości bliźniego, wprowadzania pokoju. Kościół ma zleconą przez Chrystusa posługę jednania ( 2 Kor 5,18$)$. Jedna ludzi z Bogiem, z samymi sobą i mię-

Tamże, s. 57-61. 
dzy sobą. Wydarzeniem uwyraźniającym argument rekoncyliacyjny w czasie pontyfikatu Jana Pawła II była liturgia pokutna pierwszej niedzieli Wielkiego Postu w 2000 roku, w czasie której papież przebaczył krzywdy wyrządzone chrześcijanom i przeprosił za ich winy. Być może dziś świat już mało pamięta, że za tego pontyfikatu i dzięki papieskim staraniom doszło do złagodzenia napięć m.in. w Irlandii, Hiszpanii oraz między Anglią a Argentyną.

\subsection{Argument sperancyjny ${ }^{6}$}

W swym nauczaniu Jan Paweł II dał liczne podstawy do formułowania argumentu sperancyjnego (łac. spes - nadzieja) na rzecz wiarygodności Kościoła. Odnosi się on zarówno do przeszłości, jak i teraźniejszości oraz przyszłości, a polega na tym, że Eklezja zawsze miała i ma źródło trwałej nadziei nie tylko na sensowny kres dziejów w postaci eschatologii (np. Ap 21, 1-4 - „nowe niebo i nowa ziemia”), lecz także mobilizującej do pozytywnych działań w trakcie historii. W Europie były i są różne poglądy co do przyszłości. W starożytności przedchrześcijańskiej mówiono o fatum, zależności losu od nieprzewidywalnych decyzji bogów. Później o determinizmach „z góry” wyznaczających teraźniejszość i przyszłość człowieka lub utopiach obiecujących szczęśliwą przyszłość w nieokreślonym czasie, które zawsze okazywały się niespełnione. Dzisiejsza Europa - według papieża w duchu nihilizmu i katastrofizmu lęka się przyszłości lub wątpi w jej pozytywny kształt. Wraz z odrzucaniem chrześcijaństwa i Kościoła pozbawia ona siebie nadziei?

Tymczasem Kościół żyje nadzieją zakotwiczoną przede wszystkim w całej historii zbawienia i zmartwychwstaniu Jezusa Chrystusa, które zapowiada eschatologiczną przemianę człowieka i świata. Wyraźnie mówi o ostatecznym pokonaniu zła i śmierci oraz o Bożym sądzie nad historią i ludzkimi czynami, który wynagrodzi dobro i potępi zło, tym samym zapewniając ludzkiej egzystencji sensowność. Według Jana Pawła II Kościół wielokrotnie w przeszłości sprawdził się pod względem sperancyjnym, gdyż w okresach utraty nadziei będącej skutkiem dramatycznych wydarzeń potrafił na nowo ją zaszczepić. Czyni to także dziś, mimo obecnych w Europie kulturowego znużenia, lęków o przyszłość, nihilizmu i katastrofizmu oraz widocznego braku odpowiedzialności za przyszłe losy ludzi i społeczeństw.

Tamże, s. 261-266.

7 Jan Paweł II, adhort. Ecclesia in Europa, zwł. 18, 106. 


\subsection{Argument martyrologiczny}

$\mathrm{Z}$ argumentem sperancyjnym wiąże się ściśle - w ujęciu Jana Pawła II argument martyrologiczny (gruntownie opracowywany przez teologię fundamentalną ${ }^{9}$ ), czyli ze świadectwa dawanego przez chrześcijan, świętych, błogosławionych, męczenników, świętych anonimowych, reprezentantów różnych grup społecznych ${ }^{10}$. Nigdy w dziejach Kościoła i Europy ich nie zabrakło. To oni odnawiali i odnawiają nadzieję, tak bardzo potrzebną każdemu człowiekowi. Ich postawę należy odczytywać w sposób religijny, czyli w powiązaniu z Bożym objawieniem i istotnymi zadaniami Kościoła. Nie jest też bez znaczenia, choć papież raczej nie sugerował tego wprost, że ci świadkowie odgrywali i odgrywają rolę pozytywną także w płaszczyźnie naturalnej, ludzkiej, gdyż udowadniają, że można przeżyć swe życie w sposób sensowny, szlachetny, wręcz heroiczny, i to pomimo niesprzyjających okoliczności historycznych. Zawsze tacy świadkowie prowokują pytanie: $\mathrm{z}$ jakich powodów to czynili i skąd czerpali siłę?

Choć skuteczność argumentu martyrologicznego jest oczywiście osłabiana przez przykłady antyświadectwa dawanego przez członków Kościoła zarówno w przeszłości, jak i obecnie, to jednak nie jest on przez nie obalony. O ile stosunkowo łatwo w sposób naturalny wytłumaczyć przyczyny postaw będących antyświadectwem (jakkolwiek każde antyświadectwo chrześcijan jest bolesne i zmniejsza wiarygodność Kościoła), o tyle nie jest możliwe tylko w kategoriach naturalnych wyjaśnienie postaw wyjątkowych, heroicznych.

\subsection{Argument misyjny ${ }^{11}$}

Na podstawie nauczania Jana Pawła II można sformułować argument misyjny obejmujący kilka elementów, jak aktywność misyjna Kościoła w całych dziejach Europy ad intra i ad extra (Kościół europejski dał światu największą liczbę misjonarzy) oraz jej kontynuowanie, dziś zwłaszcza w formie ad intra.

$8 \quad$ K. Kaucha, Wiarygodność Kościoła w kontekście wyzwań współczesności europejskiej w świetle nauczania Jana Pawła II, dz. cyt., s. 266-271.

9 Zob. np. G. Dziewulski, Świadectwo chrześcijańskie jako znak wiarygodności Kościoła, Lublin 2010.

10 Coraz częściej dziś mówi się w teologii o heroizmie codziennego świadectwa chrześcijańskiego. Np. M. Rusecki, Traktat o wiarygodności chrześcijaństwa. Dlaczego wierzyć Chrystusowi?, Lublin 2010, s. 150-169.

11 K. Kaucha, Wiarygodność Kościoła w kontekście wyzwań współczesności europejskiej w świetle nauczania Jana Pawła II, dz. cyt., s. 272-277. 
Tu zwróci się uwagę na ten ostatni element $\mathrm{z}$ racji jego argumentacyjnego waloru.

We współczesnej Europie Kościół podejmuje działalność misyjną nazywaną nową ewangelizacją lub reewangelizacją (inspirowaną nauczaniem i przykładem papieża Polaka), która jest bodaj najtrudniejszym rodzajem misji ${ }^{12}$. Dlaczego? Ponieważ odbywa się ona na terenach od dawna chrześcijańskich, które przeżywają kryzys, a nawet regres swej religijnej tożsamości, co widoczne jest nie tylko w statystykach, lecz także w wielu zjawiskach kulturowo-społecznych. Wydaje się, iż chrześcijaństwo i Kościół „przegrywają” z sekularyzacją, laicyzacją, pluralizmem religijnym i kulturowym. Można obserwować u dzisiejszych Europejczyków brak znajomości chrześcijaństwa, kultywowanie tylko zwyczajów wywodzących się z tej religii pozbawione jednak wiary, a także jakieś zmęczenie chrześcijaństwem i Kościołem, któremu na Starym Kontynencie nieustannie przypomina się jego winy i słabości z przeszłości. Europa znana jest też z ciągłego pragnienia czegoś nowego, także w sferze religijnej, dlatego jej mieszkańcy „eksperymentują” poprzez zainteresowanie się innymi religiami lub propozycje pseudo-religijne.

Trzonem prezentowanego w tym kontekście argumentu misyjnego byłby zatem fakt, iż Eklezja w Europie nie zrezygnowała z działalności misyjnej i ma jeszcze siły do nowej ewangelizacji, która przynosi efekty w formie prowadzenia nieochrzczonych do wiary i chrztu, a ochrzczonych do nawrócenia. Może nie są to rezultaty bardzo spektakularne, lecz należy pamiętać o wyjątkowo trudnych uwarunkowaniach współczesnej działalności misyjnej na Starym Kontynencie. W dużej mierze prowadzą ją „dzieci” współczesnej Europy, nierzadko wychowywane w atmosferze niesprzyjającej chrześcijaństwu lub antychrześcijańskiej.

\section{Argumenty duchowo-moralne}

Jan Paweł II traktował wymiar duchowo-moralny jako najważniejszy, jako rdzeń ludzkiej egzystencji. Nawiązując do tego, można na podstawie papieskiego nauczania sformułować trzy argumenty na rzecz wiarygodności Kościoła: antropologiczno-wokatywny, metafizyczny i etyczny.

12 Zob. np. R. Skrzypczak, Kościół misyjny według Jana Pawła II, Lublin 2005. 


\subsection{Argument antropologiczno-wokatywny ${ }^{13}$}

Składa się on z dwóch filarów, antropologicznego i wokatywnego, ściśle powiązanych ze sobą. Podstawy pierwszego nie wymagają szerszej prezentacji, ponieważ literatura na ten temat jest bardzo obszerna ${ }^{14}$. Teologii fundamentalnej zależy jednak na wydobyciu wniosków wiarygodnościowych płynących z antropologii Jana Pawła II i dotyczących Eklezji, a jest ich wiele. Ogólnie rzecz ujmując, Kościół jest antropologicznie wiarygodny, ponieważ głoszona przezeń objawiona antropologia strzeże transcendentnego wymiaru ludzkiej egzystencji, traktuje człowieka jako osobę, czyli najdoskonalszy sposób bytowania, uzasadnia jego niezbywalną godność i prawa, motywuje do samorozwoju, daje pełną i pozytywną odpowiedź na egzystencjalne pytania o sens życia, cierpienia i śmierci ${ }^{15}$. W ramach argumentacji koniecznie trzeba dodać, iż współcześnie panują, zwłaszcza w Europie, chaos i relatywizm antropologiczny, a także tendencje do ujmowania człowieka w kategoriach materialistycznych i biologicznych.

Drugi filar argumentu antropologicznego jest bardzo oryginalny. Obecnie - według Jana Pawła II - antropologia zarzuciła czynnik wokatywności. Panuje model człowieka „bez powołania” do czegokolwiek, zwłaszcza wyższych ideałów. Tymczasem antropologia Kościoła mocno akcentuje ludzką wokatywność, której podstawy znajdują się zarówno w naturze ludzkiej, jak i objawieniu chrześcijańskim. W myśli papieża antropologia wokatywna najpełniej pasuje do osobowego bytu człowieka i jest jego konsekwencją, którą Kościół od początku istnienia włączył do swej praxis.

\subsection{Argument metafizyczny ${ }^{16}$}

Należy on do grupy oryginalnych argumentów mających podstawy w nauczaniu Jana Pawła II. Wychodzi on od wzajemnego związania Kościoła i metafizyki ujętej w jej podstawowym znaczeniu, jako ogólna wizja całej rzeczywistości dążąca do wskazania jej ontycznych i aksjologicznych podstaw. Papież zdawał sobie sprawę z nieprzychylnego współczesnego klimatu wokół

${ }^{13}$ K. Kaucha, Wiarygodność Kościoła w kontekście wyzwań współczesności europejskiej w świetle nauczania Jana Pawła II, dz. cyt., s. 101-114.

14 Tamże, s. 98, przyp. 149, s. 108, przyp. 193.

15 Zob. T. Kostecki, Antropologiczna wiarygodność Kościoła i jej uzasadnianie w świetle nauczania Jana Pawła II, Lublin 2015 [mps rozprawy doktorskiej obronionej w KUL 12.03.2015, ss. 341].

16 K. Kaucha, Wiarygodność Kościoła w kontekście wyzwań współczesności europejskiej w świetle nauczania Jana Pawła II, dz. cyt., s. 114-120. 
metafizyki, jej wewnętrznego kryzysu, fragmentaryzacji wiedzy i poznania filozoficznego. Tym bardziej przypominał, że człowiekowi w każdej epoce towarzyszy „niepokój metafizyczny” i pragnienie zrozumienia całej rzeczywistości. Na kanwie tego wskazywał obszerne pokłady treści metafizycznych obecnych w objawieniu chrześcijańskim oraz nauce Kościoła. Dotyczy to np. prawdy o Bogu, człowieku, eschatologii, zmartwychwstaniu. Ponadto Eklezja jako historyczna wspólnota Bosko-ludzka z natury swej jest głęboko metafizyczna.

\subsection{Argument etyczny ${ }^{17}$}

Ma on szerokie podstawy w nauczaniu papieża - etyka wyczulonego na współczesne problemy moralno-etyczne. Potwierdzeniem tego mogą być jego częste ostrzeżenia przed „cywilizacją śmierci i nienawiści”, poruszanie problematyki sumienia oraz wyjątkowo „mocny” sposób nauczania o niemoralności świadomego zabójstwa niewinnej osoby ludzkiej, aborcji i eutanazji $\mathrm{w}$ encyklice Evangelium vitae ${ }^{18}$. Choć papież nie wyraził się tam w formie nadzwyczajnej, uroczystej, lecz tzw. nauczania zwyczajnego, to jednak waga jego słów jest szczególna.

Argument etyczny za wiarygodnością Kościoła odwołuje się przede wszystkim do podstaw moralności głoszonej przez Eklezję, którymi są normy i zasady etyczne wyprowadzone z objawienia chrześcijańskiego i prawa naturalnego, akcentujące zwłaszcza tzw. normę personalistyczną (godność osoby ludzkiej). Papież zwracał uwagę na niezmienność i uniwersalność tych norm oraz prymat prawdy (każdej, w tym etycznej) przed wolnością i innymi wartościami. Przekonywał, że wartości uzyskują status wartości właśnie dzięki zgodności z obiektywną prawdą etyczno-moralną odkrywaną przez sumienie. Argumentował, że ta prawda została powierzona Kościołowi, a on ją konsekwentnie głosił i głosi światu, wydobywając z niej konkretne wskazania moralne.

Dla Jana Pawła II było oczywiste, iż etyczną wiarygodność Eklezji wzmacniają skutki współczesnego podważania czy wprost odrzucania nauczania Kościoła w sferze moralnej. Zwracał on uwagę na paradoks polegający na tym, że chociaż w dzisiejszej Europie dużo mówi się o etyce i prowadzi licz-

\footnotetext{
17 Tamże, s. 120-126.

18 Jan Paweł II, enc. Evangelium vitae 57, 62, 65. Por. S. Nagy, Problem stopnia teologicznej pewności nauki encykliki „Evangelium vitae”, [w:] Jan Paweł II, Evangelium vitae. Tekst i komentarze, red. T. Styczeń, J. Nagórny, Lublin 1997, s. 237-245.
} 
ne debaty etyczno-moralne, to jednak ustanawia się coraz więcej rozwiązań sprzecznych z podstawowymi normami i zasadami etycznymi. Mówił też, iż Kościół jest dziś praktycznie osamotniony w walce o respektowanie godności każdej ludzkiej osoby, jej prawa do życia od poczęcia do naturalnej śmierci oraz obrony autonomii sumienia. W nauczaniu papieża były też poruszane wątki apologijne, np. wobec zarzutów, że Kościół nie powinien narzucać swej nauki moralnej, a jedynie może do niej zachęcać; że powinien zachowywać postawę wyrozumiałości wobec ludzkich słabości w sferze moralnej, a nie karać. Jan Paweł II odpowiadał na wiele tych i tym podobnych zarzutów.

\section{Argumenty kulturowo-społeczne}

W wyniku podjętych badań na podstawie nauczania Jana Pawła II udało się sformułować trzy argumenty natury kulturowo-społecznej, a mianowicie kulturotwórczy, aksjologiczny i komuniotwórczy.

\subsection{Argument kulturotwórczy ${ }^{19}$}

Argument ten, szeroko szkicowany w nauczaniu Jana Pawła II, powinien być wyróżniony, ponieważ zagadnieniu kultury papież poświęcał wiele uwagi. Literatura na ten temat jest bardzo bogata ${ }^{20}$, lecz nie zajmuje się ona wiarygodnościowym wymiarem tego papieskiego nauczania, dlatego tym bardziej trzeba go wydobyć.

Argument kulturotwórczy - który jako pierwszy zaczął opracowywać ks. prof. Marian Rusecki ${ }^{21}$ - polega na wykazywaniu kilku własności Kościoła, a mianowicie, że na przestrzeni swych dziejów zawsze motywował do tworzenia kultury w pełni odpowiadającej naturze człowieka i jego najwyższym aspiracjom, podnosił zastane kultury na wyższy poziom, rozwijając ich cenny dorobek i jednocześnie usuwając z nich błędy, w Europie dzięki jego oddziaływaniu powstała kultura stanowiąca tożsamość tego kontynentu oraz że sam Kościół jest oryginalną kulturą. O ile niektóre z tych własności Eklezji są

19 K. Kaucha, Wiarygodność Kościoła w kontekście wyzwań współczesności europejskiej w świetle nauczania Jana Pawła II, dz. cyt., s. 163-169.

20 Tamże, s. 130, przyp. 1.

21 M. Rusecki, Kulturotwórczy argument, [w:] Leksykon teologii fundamentalnej, red. M. Rusecki i in., Lublin-Kraków 2002, s. 730-742; tenże, Fenomen chrześcijaństwa. Wkład w kulturę, Lublin 2001; tenże, Traktat o wiarygodności chrześcijaństwa. Dlaczego wierzyć Chrystusowi?, Lublin, s. 292-329; tenże, Dziejowe znaczenie chrześcijaństwa, Poznań 2011. 
oczywiste, a ich dowodami są arcydzieła europejskiej myśli i sztuki ${ }^{22}$, o tyle inne są jakimś odkryciem dokonanym dzięki światłu papieskiego nauczania. Głównie dotyczy to spojrzenia na Kościół, Ewangelię i główne wydarzenia historii zbawienia (np. wcielenie, krzyż, zmartwychwstanie) jako na kulturę. To kultura, a nawet cywilizacja, życia, miłości, prawdy, dobra, wolności, nadziei, radości, pokoju i innych wartości.

Wzmocnieniem argumentu kulturotwórczego w myśli Jana Pawła II była jego diagnoza współczesnej kultury europejskiej, która popada w kryzys tym bardziej, im dalej odchodzi od chrześcijaństwa. Jan Paweł II określał tę kulturę mianem chwiejnej, jednowymiarowej, horyzontalnej, materialistycznej, konsumpcjonistycznej, hedonistycznej, pragmatycznej, relatywistycznej i nierzadko nihilistycznej. Przekształca się ona w „kulturę śmierci i nienawiści” (a zatem antykulturę), wypalenia i obojętności. Już nie tyle jest wytworem człowieka jako jej podmiotu, ile coraz częściej to on staje się jej produktem. Według papieża przed Kościołem w Europie stoi dziś zadanie „nowej ewangelizacji kultury”. Eklezja jest gotowa je podjąć i czyni to, zaś efekty są uzależnione od otwarcia się kultury europejskiej - znajdującej się obecnie w stanie przejściowym - na Ewangelię.

\subsection{Argument aksjologiczny ${ }^{23}$}

Jego zrąb został wskazany w prezentacji argumentu kulturotwórczego, gdyż głównym filarem kultury są wartości. Argument aksjologiczny jest analogiczny do kulturotwórczego i polega na wykazywaniu, że Kościół zaszczepiał i zaszczepia wartości odpowiadające ludzkiej naturze oraz najwyższym aspiracjom człowieka, że czerpie te wartości z wiarygodnego źródła, jakim jest Boże objawienie, i że sam jest aksjologią, czyli od swego początku przepełniony jest wartościami, które stanowią jego naturę i tożsamość. Pionierem jego opracowywania był, jak w przypadku argumentu kulturotwórczego, ks. Marian Rusecki ${ }^{24}$.

Jan Paweł II nauczał, że Eklezja rodzi kulturę i jest kulturą następujących wartości: życia, miłości, osoby, prawdy, dobra, piękna, sensu, wolności, na-

22 R. Knapiński, Sztuka chrześcijańska, [w:] Leksykon teologii fundamentalnej, dz. cyt., s. $1171-1187$.

${ }^{23}$ K. Kaucha, Wiarygodność Kościoła w kontekście wyzwań współczesności europejskiej $w$ świetle nauczania Jana Pawła II, dz. cyt., s. 170-184.

24 M. Rusecki, Traktat o wiarygodności chrześcijaństwa. Dlaczego wierzyć Chrystusowi?, dz. cyt., s. 356-374. 
dziei, radości, pokoju, miłosierdzia, sprawiedliwości, przebaczenia, pojednania, solidarności, otwartości, dialogu, jedności, świętości, odpowiedzialności i bezinteresowności. Według papieża w Kościele wartości te są autentyczne, czyli obecne nie w postaci tylko haseł czy jakichkolwiek niedoskonałości czy wypaczeń ${ }^{25}$. Kryterium ich wiarygodności jest to, że są kulturotwórcze, sensotwórcze i osobotwórcze. Należy rozszerzyć papieskie określenie odnoszące się do prawdy (veritatis splendor) na wszystkie autentyczne wartości i stwierdzić, że płynący z nich blask to właśnie ich piękno i wiarygodność powodująca w człowieku „autodeterminację ku wartościom”.

Ponadto za aksjologiczną wiarygodnością Kościoła przemawia - według myśli Jana Pawła II - prymat wartości duchowo-moralnych przed innymi oraz ich stała hierarchia, na której szczycie jest Bóg jako Wartość Najwyższa i źródło wartości, w dalszej kolejności osoba jako wartość najwyższa w porządku doczesnym, a potem świat stworzony. Papież Polak zwracał uwagę, iż we współczesnej Europie ma miejsce kryzys wartości, odwrócenie hierarchii wartości oraz są głoszone pseudowartości, a nawet antywartości. Dlatego zadaniem Kościoła jest nowa ewangelizacja wartości.

Warto w tym miejscu zastanowić się, jaka jest siła motywacyjna i skuteczność nie tyle samego argumentu aksjologicznego, ile przede wszystkim wartości chrześcijańskich, skoro wydają się oczywiste i pożądane, a jednocześnie widać w dzisiejszej Europie dystansowanie się od Kościoła. Wiarygodność wartości chrześcijańskich, czy w ogóle wartości, rozpoznaje się wtedy, gdy się w nich zasmakuje, czyli podejmie się próbę ich realizacji. Tylko wtedy pojawią się ich skutki decydujące o wiarygodności. Trzeba też przyznać, że w Kościele zdarzają się braki aksjologiczne. Nie zawsze i nie wszędzie ludzie Eklezji czy jej instytucje zachowują prymat wartości, ich hierarchię i autentyzm. To oczywiście jest przyczyną osłabienia wiarygodności Kościoła. Ponadto mylący jest pogląd - na co zwracał uwagę ks. Rusecki - że wartości chrześcijańskie to nic innego jak wartości ogólnoludzkie. Każda wartość chrześcijańska ma zarówno stronę ogólnoludzką (i w tym sensie łatwo ją przyjmować), jak i nadprzyrodzoną, wymagającą wiary, czynu i zaangażowa-

25 Papież często dodawał do wartości przymiotnik „autentyczny”. Zwracał tym uwagę, że wartości są na ogół cenione i pożądane przez wszystkich, jednak ich autentyczność zależy od ich rozumienia. Np. dziś słusznie ceni się prawdę, lecz czy dąży się do całej prawdy? Ceni się wolność, lecz czy właściwie się ją pojmuje? Czy „wolność od” to cała prawda o wolności, wolność autentyczna? 
nia, a często też trudnych zmagań, co stwarza realne trudności z akceptacją jej wiarygodności ${ }^{26}$.

\subsection{Argument komuniotwórczy ${ }^{27}$}

Przyjęło się mówić, że człowiek ze swej natury jest istotą społeczną, dlatego tworzy różne formy życia społecznego. To oczywiście słuszne, lecz Jan Paweł II dodałby, że z natury swej człowiek jest istotą nie tyle społeczną, ile wspólnotową, komunijną, i nie może jako osoba żyć bez ścisłych więzi z innymi osobami, wchodząc w relacje wspólnotowe (communio personarum). Ta jego uwaga jest podstawą argumentu komuniotwórczego.

Polega on na wykazywaniu, że Kościół Chrystusowy, od swego początku będąc jedyną w swoim rodzaju Bosko-ludzką wspólnotą (Communio, Koinonia), w której więzy łączące Boga z ludźmi i ludzi między sobą są najściślejsze, na przestrzeni dziejów realizował i realizuje ludzkie zapotrzebowanie na życie wspólnotowe. W Europie Kościół dał początek civitas christiana - cieszącej się jednością i wprowadzającej doń nowe ludy oraz narody poprzez sakrament chrztu. Włączane do wspólnoty świata chrześcijańskiego, Eklezji, wkraczały one - według papieża - na drogę szybkiego rozwoju kulturowo-społecznego, uzyskując podmiotowość i godność. Jan Paweł II nie zgodziłby się z opinią, iż Kościół czy ogólniej religia był przyczyną utraty jedności i wspólnotowości narodów chrześcijańskich na Starym Kontynencie. Prawdą jest, że w jego dziejach pojawiły się rozłamy na tle religijnym i antagonizmy z tym związane, lecz nie było to winą Eklezji jako takiej, lecz zaniedbań czy grzechów ludzi Kościoła, a także skutkiem działań pozareligijnych, a mianowicie politycznych i ekonomicznych.

Warto w tym miejscu choćby bardzo skrótowo przypomnieć elementy papieskiego nauczania przekonujące o komunijnej i komuniotwórczej naturze Kościoła. Jest on Communio Personarum et personarum i wywodzi się z wewnętrznej jedności Trójcy Świętej („Boga-Komunii”). Fundamentem ontologicznej jedności i wspólnotowości Eklezji jest jeden i powszechny Boży plan zbawienia, jedna pełnia Bożego objawienia, jedno misterium wcielenia, jedno misterium paschalne Jezusa Chrystusa, a także nowe przykazanie miłości ma-

26 M. Rusecki, Co to sa wartości chrześcijańskie?, [w:] Problemy współczesnego Kościoła, red. M. Rusecki, Lublin 1996, s. 511-520; tenże, Chrześcijańskie wartości podstawa jedności Europy, [w:] Chrześcijaństwo a jedność Europy, red. E. Cyran, A. Czaja, P. Gutowski, Lublin 2006, s. 213-240.

${ }^{27}$ K. Kaucha, Wiarygodność Kościoła w kontekście wyzwań współczesności europejskiej $w$ świetle nauczania Jana Pawła II, dz. cyt., s. 184-194. 
jącej obejmować Boga i każdego człowieka jako bliźniego, jedność Dwunastu i jego sukcesora w postaci kolegium biskupów, jedyność posługi Piotra w gronie Dwunastu i odpowiadająca mu rola biskupa Rzymu w kolegium biskupów, jedno Magisterium Kościoła odpowiadające za jedność wiary, jedność znaczenia i skuteczności sakramentów w całej Eklezji, jeden Duch wzbudzający wiele charyzmatów mających służyć jedności Ciała oraz Eucharystia jako szczególny sakrament jedności, równości, zespolenia z Bogiem i innymi ludźmi, najwyższej wspólnotowości.

Na kanwie nauczania Jana Pawła II można powiedzieć, że cała ludzkość zawsze tęskniła i nadal tęskni za Kościołem, ponieważ pragnie osiągnąć jedność w rodzinie ludzkiej, a mimo rozlicznych starań w przeszłości i obecnie nigdy nie udało się jej tego osiągnąć. Argumenty przemawiające za komuniotwórczą wiarygodnością Eklezji są zatem w myśli papieskiej liczne i głębokie.

\section{Argumenty polityczno-ekonomiczne}

W Jana Pawła II hierarchii wymiarów rzeczywistości ludzkiej polityczno-ekonomiczny znajdował się na ostatnim miejscu, jednak i w nim papież widział pozytywne oddziaływanie Kościoła. Jego nauczanie daje podstawy do sformułowania argumentu prakseologicznego, $\mathrm{z}$ wolności religijnej oraz z projektu Kościoła co do integracji europejskiej.

\subsection{Argument prakseologiczny ${ }^{28}$}

Sam w sobie jest on w teologii fundamentalnej nowatorski. Zaczął go opracowywać ks. Ruseckii ${ }^{29}$. W odniesieniu do wiarygodności Kościoła w kontekście wyzwań współczesności europejskiej polega on na wykazywaniu, że Eklezja kieruje się objawieniem zawierającym wskazania do kształtowania praxis w pełni odpowiadającej ludzkiej godności i potrzebom pełnej realizacji osoby ludzkiej i że realnie wprowadzała oraz wprowadza je w życie. Nie sposób przedstawić tu wszystkich przesłanek tego argumentu obecnych w nauczaniu Jana Pawła II. Trzeba się ograniczyć do najważniejszych i tylko dotyczących sfery polityczno-ekonomicznej.

28 Tamże, s. 219-228.

${ }_{29}$ Ten argument, a także jego podstawy zostały pogłębione i opracowane przez ks. Rafała Pokrywińskiego w rozprawie doktorskiej Prakseologiczna koncepcja Bożego Objawienia i jego wiarygodność w świetle wybranej literatury [mps, Lublin 2015]. 
Papież zwracał uwagę na to, że Kościół w dziejach Europy oczyścił ją ze starożytnych ograniczeń i niesprawiedliwości w postaci niewolnictwa, zawężonej demokracji, totalitaryzmu Imperium Rzymskiego. Dążył do chrystianizacji koncepcji władzy politycznej i praktycznych sposobów jej wykonywania. Wprawdzie w XIX wieku, gdy powstała tzw. kwestia społeczna (robotnicza), reakcja Magisterium była nieco spóźniona, jednak później coraz częściej wypowiadało się ono w sprawach społecznych, politycznych i ekonomicznych, co doprowadziło do ukształtowania się katolickiej nauki społecznej oraz nauczania Kościoła w tak ważnych kwestiach jak pokój, sprawiedliwość, ubóstwo. W XX wieku - według Jana Pawła II - zasługą Eklezji była odważna krytyka ideologicznych systemów totalitarnych w Europie. Kościół inspirował tzw. rewolucję sumień w 1980 roku i jesień ludów od 1989 roku. Tym samym dowiódł swego umiłowania wolności, sprawiedliwości, pokoju, praw człowieka i solidarności. Obecnie nadal jest zapotrzebowanie na właściwą praxis $\mathrm{w}$ dziedzinie polityczno-ekonomicznej, gdyż Stary Kontynent nie radzi sobie z nowymi obszarami ubóstwa i niesprawiedliwości, zjawiskiem nasilonej imigracji, biurokracją, korupcją, odejściem demokracji od pierwotnego ideału, cynizmem w świecie polityki i utopią niewidzialnej ręki wolnego rynku. Papież widział rolę Kościoła nie $\mathrm{w}$ formie zaangażowania się w konkretne działania polityczne czy ekonomiczne, lecz w kształtowaniu właściwej koncepcji polityki, władzy, ekonomii, wolnego rynku i demokracji.

W ramach tego argumentu nie sposób nie przywołać jego osobistego prakseologicznego wkładu choćby w postaci encyklik społecznych (Laborem exercens, Sollicitudo rei socialis, Centesimus annus), teologii pracy czy wskazań dotyczących nowych obszarów ubóstwa i wykluczenia w Europie.

\subsection{Argument $z$ wolności religijnej ${ }^{30}$}

Myśl, by uwiarygodniać Kościół w powiązaniu z wolnością religijną, może być odebrana jako jawna prowokacja. Niektóre środowiska europejskie są przekonane, że Kościół tę wolność tłumił, a początek Europie dała dopiero rewolucja francuska, wprowadzając ostry rozdział państwa od Kościoła i religii. Zarzuca się też Eklezji - przed czym Jan Paweł II nie oponował - bezpośrednie angażowanie się w przeszłości do polityki i ekonomii, bynajmniej nie w celach religijnych czy z pobudek humanistycznych, lecz by zyskiwać

$30 \quad$ K. Kaucha, Wiarygodność Kościoła w kontekście wyzwań współczesności europejskiej w świetle nauczania Jana Pawła II, dz. cyt., s. 228-234. 
przywileje. Wytyka się też działanie inkwizycji i wojny religijne, które spowodowały wiele ofiar i nienawiści.

W tym kontekście warto jednak zwrócić uwagę na kilka zagadnień poruszanych przez papieża. Nauczał on, że w przeszłości niektóre działania ludzi Kościoła i jego instytucji były rzeczywiście niewłaściwe, a nawet gorszące, i stały w sprzeczności z zasadą wolności religijnej. Jednocześnie przypominał, że w średniowieczu udało się wypracować rozdział państwa od Kościoła oraz mechanizm współpracy władzy świeckiej z religijną, że zasada cuius regio eius religio wprowadzona w XVI wieku nie zapewniła wolności religijnej, lecz ją praktycznie odebrała, że rewolucja francuska przyniosła ze sobą wiele ofiar, i że zapoczątkowała nową formę religijnej niewoli w postaci ograniczenia prawa do wolności religijnej (ideologizujący fundamentalizm laicki). W XX wieku Kościół był prześladowany - na miarę tych z pierwszych wieków - ze strony ateistycznych ideologii totalitarnych z powodu rzekomej wolności religijnej. Dzisiaj Kościół nie boi się wolności religijnej, a nawet o nią zabiega i przypomina władzy politycznej o jej respektowaniu ze względu na prawa człowieka ${ }^{31}$. Ponadto Eklezja nikomu nie narzuca wiary ani zasad z niej płynących, lecz pozostawia wolność ich akceptacji ludzkiemu sumieniu. Nie wiąże się z żadną siłą polityczną czy ekonomiczną ani nie dąży do tworzenia państwa wyznaniowego.

\subsection{Argument z projektu Kościoła co do integracji europejskiej ${ }^{32}$}

Zainteresowanie Jana Pawła II procesem integracji europejskiej, ocenianym przez niego jako idea bardzo pozytywna, było wyraźne, o czym może świadczyć ogromna liczba opracowań temu poświęconych ${ }^{33}$. Jeśli spojrzeć na jego nauczanie przez pryzmat wiarygodności Kościoła, to rysuje się możliwość sformułowania odrębnego argumentu na jej rzecz.

Głównymi jego przesłankami są dziejowe dokonania Kościoła w zakresie scalania i jednoczenia Europy - o czym już szeroko w tym artykule mówiono, zastój integracji kontynentu zapoczątkowanej w połowie XX wieku oraz propozycje Kościoła co do tej integracji, mające kształt projektu. Według papieża integracja europejska obecnie spowolniła, a jej realizacja zaczęła odbiegać od zamysłu ojców założycieli, jak Jean Monet, Robert Schuman, Alcide De Gasperi, Konrad Adenauer, Winston Churchill i Paul-Henri Spaak, i skon-

\footnotetext{
31 Zob. obszerną bibliografię: tamże, s. 228, przyp. 145.

32 Tamże, s. 234-239.

33 Tamże, s. 234, przyp. 169.
} 
centrowała się na integracji polityczno-ekonomicznej, pomijając działania w zakresie kultury, etyki, wartości i odpowiadającego im prawa. Wkrada się ideologizujący relatywizm podważający koncepcję osoby i rodziny oraz ograniczający podstawowe prawa, np. fundamentalne prawo do życia każdej istoty ludzkiej od poczęcia do naturalnej śmierci.

Kościół, respektując autonomię porządku cywilnego, proponuje rozpocząć jednoczenie Starego Kontynentu od budowy - czy też odbudowy - cywilizacji europejskiej osadzonej na słusznych i wypróbowanych w jej dziejach ideach, zasadach i wartościach. Projekt Kościoła wypływa z integralnej koncepcji rozwoju człowieka i świata. Zapewnienie takiego rozwoju jest koniecznym warunkiem powodzenia zamysłu. Integralność polegałaby na korelacji rozwoju Europy z rozwojem świata (a nie przeciw niemu, w duchu konkurencji czy europejskiego egoizmu), uwzględnieniu prawdy o całej naturze ludzkiej (duchowo-cielesnej, społecznej, komunijnej) i odpowiedniej hierarchii wartości (najpierw duchowo-moralnych i kulturowo-społecznych, a potem polityczno-ekonomicznych). Projekt proponowany przez Eklezję - jak przypominał Jan Paweł II - zbudowany jest na obiektywnych zasadach i wartościach moralnych, jak nienaruszalna godność każdej osoby ludzkiej, prawa człowieka, centralna rola rodziny i jej praw, wolność religii i sumienia, ideologiczna neutralność państwa, zasada dobra wspólnego, solidarności, pomocniczości, sprawiedliwości i miłosierdzia.

W niniejszym artykule skrótowo przedstawiono przebieg autorskich badań naukowych nad zagadnieniem wiarygodności Kościoła w kontekście wyzwań współczesności europejskiej w świetle nauczania Jana Pawła II, które okazało się najszerszym i najbardziej odpowiednim źródłem do rozwiązania przedstawionego problemu, mającego dziś ogromne znaczenie dla chrześcijaństwa. Omówiono - i to skrótowo - tylko pewien wycinek efektów tych badań w postaci piętnastu argumentów na rzecz wiarygodności Eklezji. Pominięto inne zagadnienia, jak Jana Pawła II diagnoza współczesnych wyzwań stojących przed Kościołem w Europie czy jego rozumienie Eklezji i jej wiarygodności.

Trzeba jeszcze dodać, że badania te można było przeprowadzić dzięki wielu oryginalnym pracom współtwórcy lubelskiej szkoły teologii fundamentalnej, wybitnemu teologowi i myślicielowi ks. Marianowi Ruseckiemu. 